\title{
Regresi Terboboti Geografis Semiparametrik (RTG-S) untuk Pemodelan Indeks Pembangunan Kesehatan Masyarakat Kabupaten/Kota di Sumatera Utara
}

\author{
Risti Yulianti Khoeriyah* \\ Prodi Akuntansi, Fakultas Ekonomi dan Bisnis, Universitas Islam Bandung, \\ Indonesia. \\ "ristiykh@gmail.com
}

\begin{abstract}
Geographically Weighted Regression (GWR) is a weighted regression analysis to estimate local parameters or have the spatial diversity that is where regression models at each observation point varies. Sometimes on applications there are global independent variables or global parameters, the others are the local parameters. Geographically weighted regression GWR that has local and global parameters is called Semiparametric Geographically Weighted Regression (GWR-S). The public health development index or called IPKM is a composite indicator to illustrate the progress of health development in an area. Based on that, it is good to know factors that affect the health index and in application use semiparametric geographically weighted regression models. The observation unit used is the district/city in North Sumatra Province. As a result of GWR-S models it can be concluded that percentage of households with access to freshwater sources and percentage of prevalence of of central obesity significantly affects the IPKM in every district/city in North Sumatra. Whereas the percentage of households with edequate sanitation access and population densities significantly affect IPKM at 25 locations in Nort Sumatra. GWR-S model shows the best model seen by the smallest Akaike Information Criterion Corrected (AICc) and the biggest R2.
\end{abstract}

Keywords: Geographically weighted regression, semiparametric geographically weighted regression, IPKM.

Abstrak. Regresi Terboboti Geografis (RTG) adalah suatu analisis regresi yang terboboti untuk menduga parameter yang bersifat lokal atau mempunyai keragaman spasial yang dimana model regresi di setiap lokasi pengamatan berbeda-beda. Terkadang pada pengaplikasiannya ditemukan beberapa variabel bebas atau parameter yang bersifat global, sedangkan lainnya bersifat lokal. Regresi terboboti geografis yang memiliki parameter yang bersifat global dan lokal adalah Regresi Terboboti Geografis Semiparametrik (RTG-S). Indeks Pembangunan Kesehatan Masyarakat atau yang disebut dengan IPKM adalah sebuah indikator komposit untuk menggambarkan kemajuan pembangunan kesehatan di suatu daerah. Berdasarkan hal tersebut, perlu diketahui faktor-faktor yang mempengaruhi indeks kesehatan dan dalam pengaplikasiannya menggunakan model regresi terboboti geografis semiparametrik. Unit pengamatan yang digunakan adalah kabupaten/kota di provinsi Sumatera Utara. Berdasarkan pengujian yang dilakukan dalam penerapan model RTG-S, diperoleh bahwa faktor persentase rumah tangga yang memiliki akses sumber air bersih dan faktor persentase prevalensi obesitas sentral berpengaruh secara signifikan terhadap IPKM pada setiap kabupaten/kota di Sumatera Utara. Sedangkan faktor persentase rumah tangga yang memiliki akses sanitasi layak dan faktor tingkat kepadatan penduduk berpengaruh secara signifikan terhadap IPKM pada 25 lokasi di Sumatera Utara. Model RTG-S menunjukkan model terbaik dilihat dari nilai Akaike Information Criterion Corrected (AICc) terkecil dan nilai R2 terbesar.

Kata Kunci: regresi terboboti geografis, regresi terboboti geografis semiparametrik, IPKM. 


\section{A. Pendahuluan}

Kesehatan adalah salah satu faktor penting dalam pembangunan sumber daya manusia berkualitas. Ukuran yang ditetapkan untuk membandingkan sejauh mana faktor kesehatan dalam tercapainya pembangunan kesehatan manusia berkualitas adalah Indeks Pembangunan Kesehatan Masyarakat atau dikenal dengan IPKM. IPKM merupakan suatu indikator komposit dimana tugasnya melakukan penggambaran terhadap kemajuan pembangunan kesehatan manusia di suatu daerah. Kesehatan termasuk salah satu data spasial, yang artinya data yang terdapat informasi lokasi geografis dengan sistem koordinat tertentu sebagai dasar referensinya (Djuraidah, 2020).

Dalam pemodelan geografis, model global seperti model regresi linier biasa (OLR) secara teoritis memberikan informasi lokal yang cukup andal jika tidak ada keragaman spasial berdasarkan wilayah dan dengan kata lain model OLR tidak dapat menggambarkan hubungan antar variabel dalam perbedaan yang heterogen di setiap wilayah (Hajarisman \& Karyana, 2016). Untuk mengantisipasinya digunakan model regresi yang terboboti oleh geografis.

Regresi Terboboti Geografis ialah analisis regresi terboboti untuk parameter yang bersifat lokal atau memiliki keragaman spasial yang menyebabkan parameter regresi di setiap lokasi pengamatan beragam (Fotheringham et al., 2002). Terkadang pada pengaplikasiannya ditemukan beberapa parameter atau variabel bebas yang bersifat global, sedangkan yang lain bersifat lokal. Regresi terboboti geografis yang memiliki parameter global dan lokal adalah regresi terboboti geografis semiparametrik. Sumatera utara merupakan provinsi kedua tertinggi yang mengalami penurunan peringkat nasional IPKM. Pada tahun 2013 di peringkat 10, sedangkan pada tahun 2018 di peringkat 20.

Berdasarkan uraian diatas, yang akan dibahas dalam penelitian ini adalah pemodelan Regresi Terboboti Geografis Semiparametrik (RTG-S) serta perbandingan model Regresi Terboboti Geografis (RTG) terhadap model Regresi Terboboti Geografis Semiparametrik (RTG-S) yang akan diterapkan pada Indeks Pembangunan Kesehatan Masyarakat (IPKM) di Sumatera Utara pada tahun 2018. Selanjutnya, tujuan dalam penelitian ini diuraikan dalam pokok-pokok sbb.

1. Mengetahui faktor-faktor yang berpengaruh secara global dan lokal pada Indeks Pembangunan Kesehatan Masyarakat (IPKM) di Sumatera Utara

2. Menerapkan model regresi terboboti geografis semiparametrik pada kasus Indeks Pembangunan Kesehatan Masyarakat (IPKM) di Sumatera Utara.

3. Mengetahui perbandingan model regresi terboboti geografis dan regresi terboboti geografis semiparametrik sehingga mendapatkan model yang terbaik untuk digunakan pada kasus Indeks Pembangunan Kesehatan Masyarakat (IPKM) di Sumatera Utara.

\section{B. Metodologi Penelitian}

\section{Metode Pengumpulan Data}

Pada penelitian ini menggunakan data sekunder, yaitu sebuah data yang diperoleh dari sumber yang ada. Data yang digunakan adalah data yang diperoleh dari Badan Pusat Statistik (BPS) dan Badan Penelitian dan Pengembangan Kesehatan. Unit observasi yang digunakan adalah kabupaten/kota di Sumatera Utara pada tahun 2018 yang terdiri dari 25 kabupaten dan 8 kota Sehingga secara keseluruhan adalah sebanyak 33 kabupaten/kota. Penelitian ini menggunakan data letak astronomi yang meliputi kooerdinat garis lintang (u) dan koordinat garis bujur (v) tiap kabupaten/kota di Sumatera Utara sebagai faktor pembobot geografis. Seperti pada Gambar 1.

Data yang diperlukan meliputi IPKM sebagai variabel respon (Y), persentase rumah tangga yang memiliki akses sanitasi layak $\left(\mathrm{X}_{1}\right)$, persentase rumah tangga yang memiliki akses sumber air bersih $\left(\mathrm{X}_{2}\right)$, tingkat kepadatan penduduk $\left(\mathrm{X}_{3}\right)$, persentase aktivitas fisik cukup $\left(\mathrm{X}_{4}\right)$, persentase kepemilikan jaminan pelayanan kesehatan $\left(X_{5}\right)$, persentase prevalensi obesitas sentral $\left(\mathrm{X}_{6}\right)$ 


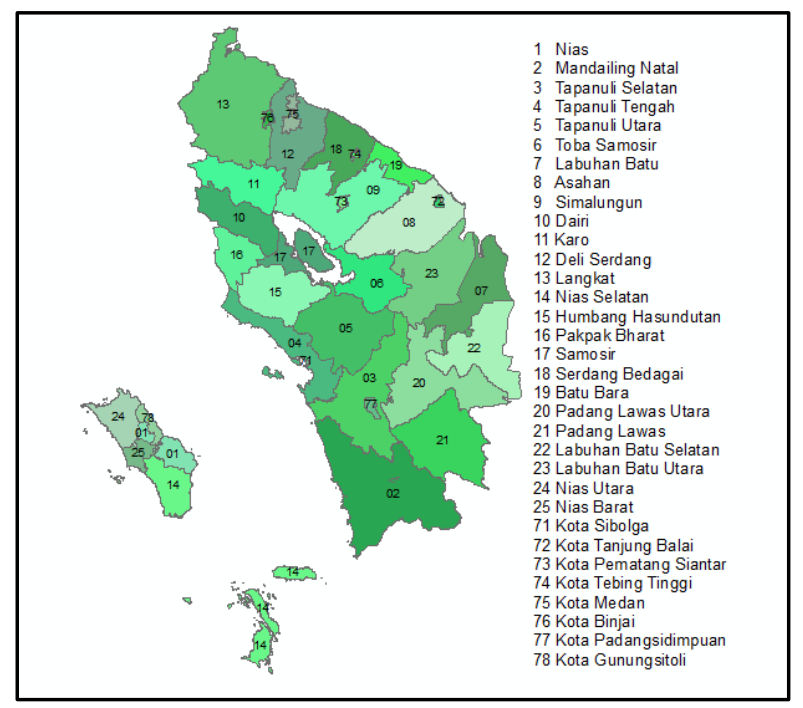

Gambar 1. Peta Tematik Sumatera Utara

\section{Metode Analisis Data}

\section{Regresi Terboboti Geografis Semiparametrik}

Regresi Terboboti Geografis Semiparametrik (RTG-S) memiliki koefisien yang beragam secara geografis maupun koefisien yang bernilai konstan dalam model yang sama (Fotheringham et al., 2002). Model RTG-S adalah sebagai berikut:

$$
y_{i}=\sum_{g=1}^{q} a_{g} x_{i g}+\sum_{l=q+1}^{p} \beta_{l}\left(u_{i}, v_{i}\right) x_{i l}+\varepsilon_{i}
$$

Dengan estimasi parameter RTG-S adalah sebagai berikut:

$$
y=X_{g} \alpha_{g}+\sum_{l=q+1}^{p} \beta_{l}\left(u_{i}, v_{i}\right) x_{i l}+\varepsilon
$$

dimana:

$\beta_{l}\left(u_{i}, v_{i}\right)$ : parameter beragam geografis (lokal) disetiap lokasi- $i$,

$a_{g} \quad$ : parameter bernilai konstan (global),

$x_{i g} \quad$ : peubah penjelas parameter global ke- $g$ pada lokasi ke- $i$,

$x_{i l} \quad$ : peubah penjelas parameter lokal ke-l pada lokasi ke- $i$,

\section{Tahapan Analisis Data}

1. Melakukan deskripsi data terhadap variabel respond dan variabel bebas untuk menentukan lokasi dengan IPKM tertinggi dan terendah.

2. Pemodelan regresi linier

a. Uji signifikansi model regresi linier

b. Uji asumsi regresi linier, yaitu: uji kenormalan galat dan melihat VIF untuk melihat ada tidaknya multikolinearitas, jika ada VIF > 10

3. Melakukan pengujian pengaruh atau efek spasial yaitu:

a. Melakukan uji Indeks Moran untuk melihat ketergantungan spasial. Digunakan hipotesis sebagai berikut:

$H_{0}: I=0$ (Tidak ada autokorelasi spasial)

$H_{1}: I \neq 0$ (Terdapat autokorelasi spasial)

dengan statistik uji Indeks Moran $\left(\mathrm{I}_{\mathrm{M}}\right)$ adalah:

$Z_{I}=\frac{I-E(I)}{\sqrt{\operatorname{Var}(I)}}$

terdapat autokorelasi spasial jika tolak $H_{0}$ dimana $\left|Z_{I}\right|>Z_{\alpha 22}$.

b. Melakukan uji Breusch-Pagan untuk melihat keragaman spasial. Hipotesisnya:

$H_{0}: \alpha_{1}=\alpha_{2}=\cdots=\alpha_{p}=0$

$H_{1}$ : paling sedikit ada satu $\alpha_{j} \neq 0$ untuk $j=1,2, \ldots, p$

dengan statistik uji Breusch dan Pagan (BP) adalah: 


$$
\begin{aligned}
& B P=\frac{1}{2}\left(\sum_{i=1}^{n} x_{i} f_{i}\right)^{\prime}\left(\sum_{i=1}^{n} x_{i} x_{i}\right)^{-1}\left(\sum_{i=1}^{n} x_{i} f_{i}\right)^{\prime} \\
& \text { terdapat keragaman spasial jika } H_{0} \text { ditolak ketika BP }>\chi^{2}{ }_{(p)}
\end{aligned}
$$

4. Pemodelan Regresi Terboboti Geografis (RTG).

a. Menentukan validasi silang minimum untuk mendapat lebar jendela optimum. dengan rumus sebagai berikut:

$$
C V=\sum_{i=1}^{n}\left[y_{i}-\hat{y}_{\neq 1}(h)\right]^{2}
$$

dimana $\hat{y}_{\neq 1}$ adalah nilai prediksi model RTG yang diduga tanpa lokasi ke-i.

b. Menghitung matriks pembobot $W j(i)$ untuk $i=1,2,3 \ldots, 33$ dan $j=1,2,3 \ldots, 33$ dengan menggunakan fungsi kernel Gaussian adaptif. Rumus sebagai berikut:

$$
w_{j}\left(u_{i}, v_{i}\right)=\exp \left(-\frac{1}{2}\left(\frac{d_{i j}}{h_{i}}\right)^{2}\right)
$$

dimana $h$ adalah lebar jendela dan $d_{i j}$ adalah jarak antara lokasi- $i$ dengan lokasi$j$ yang diformulakan sebagai berikut:

$$
d_{i j}=\sqrt{\left(u_{i}-u_{j}\right)^{2}+\left(v_{i}-v_{j}\right)^{2}}
$$

c. Menduga parameter $\hat{\beta}(i)$, melakukan uji kesesuaian model, serta uji parsial untuk membentuk model RTG

5. Pemodelan Regresi Terboboti Geografis Semiparametrik (RTG-S)

a. Menentukan parameter lokal jika pengaruh spasial tinggi dan lainnya sebagai parameter global.

b. Menduga parameter lokal dan parameter global untuk membentuk model RTGS.

c. Melakukan uji kesesuaian model, uji serentak parameter, dan uji parsial.

6. Membandingkan model RTG dan RTG-S untuk menentukan model terbaik dengan:

a. Nilai Akaike Information Criterion Coreected $\left(\mathrm{AIC}_{\mathrm{c}}\right)$. rumusnya adalah:

$$
A I C_{c}=2 n \log _{e}(\hat{\sigma})+n \log _{e}(2 \pi)+n \frac{n+\operatorname{tr}\left(S_{l}\right)}{n-2-\operatorname{tr}\left(S_{l}\right)}
$$

b. Nilai koefisien determinasi $\left(\mathrm{R}^{2}\right)$.

Model terbaik adalah jika memiliki nilai $A I C_{c}$ terkecil dan nilai $R^{2}$ terbesar.

7. Menarik Kesimpulan

\section{Hasil dan Pembahasan}

\section{Deskripsi Data}

Tabel 1 menampilkan bahwa rata-rata IPKM di Sumatera Utara sebesar 0,5854, nilai IPKM tertinggi berada di Kota Sibolga dan nilai IPKM terendah berada di Kabupaten Nias.

Tabel 1. Analisis Deskriptif Data Penelitian

\begin{tabular}{lcccc}
\hline Variabel & & Rata-rata & Minimum & Maksimum \\
\hline IPKM & $Y$ & 0,5854 & 0,4495 & 0,6772 \\
\hline $\begin{array}{l}\text { Persentase rumah tangga yang } \\
\text { memiliki akses sanitasi layak }\end{array}$ & $X_{1}$ & 61,69 & 7,40 & 95,38 \\
\hline $\begin{array}{l}\text { Persentase rumah tangga yang } \\
\text { memiliki askses sumber air bersih }\end{array}$ & $X_{2}$ & 57,00 & 29,15 & 92,48 \\
\hline Tingkat kepadatan penduduk & $X_{3}$ & 1014 & 39 & 8544 \\
\hline Persentase aktivitas fisik cukup & $X_{4}$ & 68,74 & 43,90 & 85,60 \\
\hline $\begin{array}{l}\text { Persentase kepemilikan jaminan } \\
\text { pelayanan kesehatan }\end{array}$ & $X_{5}$ & 57,28 & 39,80 & 89,20 \\
\hline Persentase prevalensi obesitas sentral & $X_{6}$ & 31,1 & 6,0 & 49,7 \\
\hline
\end{tabular}

Rata-rata persentase rumah tangga yang memiliki akses sanitasi layak di Sumatera Utara sebesar 61,69\%, persentase terendah berada pada Kabupaten Nias Selatan dan persentese tertinggi pada Kota Binjai. Rata-rata persentase rumah tangga yang memiliki akses sumber air bersih di Sumatera Utara sebesar 57,00\%, persentase terendah pada Kabupaten Nias dan 
persentase tertinggi pada Kota Pematang Siantar. Rata-rata tingkat kepadatan penduduk di Sumatera Utara sebesar 1014, persentase terendah pada Kabupaten Pakpak Bharat dan persentase tertinggi pada Kota Medan. Rata-rata persentase aktivitas fisik cukup di Sumatera Utara sebesar 68,74\%, persentase terendah pada Kabupaten Nias Selatan dan persentase tertinggi pada Kabupaten Dairi. Rata-rata persentase kepemilikan jaminan pelayanan kesehatan di Sumatera Utara sebesar 57,28\%, persentase terendah pada Kabupaten Tapanuli Selatan dan persentase tertinggi pada Kabupaten Pakpak Bharat. Rata-rata persentase prevalensi obesitas sentral di Sumatera Utara sebesar $31,1 \%$, persentase terendah pada Kabupaten Nias dan persentase tertinggi pada Kabupaten Karo.

\section{Analisis Regresi Global}

Analisis regresi global dilakukan untuk mengetahui apa saja faktor-faktor yang berpengaruh terhadap Indeks Pembangunan Kesehatan Masyarakat (IPKM) dengan tidak melibatkannya lokasi pengamatan. Pada analisis ini menggunakan software Rstudio untuk mendapatkan sebuah model. Estimasi parameter $\widehat{\boldsymbol{\beta}}$ didapat melalui metode Ordinary Least Square (OLS), sehingga model regeresi global yang terbentuk adalah sebagai berikut:

$$
\hat{y}=0,3475+9,942 e^{-04} X_{1}+1,281 e^{-03} X_{2}
$$

Berdasarkan model diatas, dapat dilihat bahwa variabel bebas yang berpengaruh terhadap IPKM di Sumatera Utara adalah persentase rumah tangga yang memiliki akses sanitasi layak dan persentase rumah tangga yang memiliki akses sumber air bersih.

Pengujian Asumsi kenormalatan galat menunjukkan bahwa nilai residual berdistribusi normal dan pengujian asumsi multikolinearitas menunjukkan bahwa tidak terdapat multikolinearitas pada masing-masing peubah berdasarkan nilai $\mathrm{VIF}<10$.

\section{Uji Efek Spasial}

Pengujian efek spasial dilakukan untuk melihat apakah setiap variabel memiliki pengaruh spasial pada lokasi atau tidak. Dengan menggunakan software Rstudio, untuk pengujian ketergantungan spasial menunjukkan belum cukup bukti terdapat autokorelasi spasial atau galat/sisaan spasial saling bebas karena nilai Indeks Moran sebesar -1,0341 dengan nilai $p$-value sebesar 0,3011 mengakibatkan $p$-value lebih besar dari taraf nyata 5\%.

Pengaruh spasial karena keragaman spasial ditunjukkan dengan ketidaksamaan ragam spasial pada galat (heteroskedasitas) sehingga digunakan uji Breusch-Pagan (BP), dengan menggunakan software Rstudio diperoleh nilai Breusch-Pagan (BP) sebesar 19,46 dengan nilai $p$-value sebesar 0,003453 mengakibatkan $p$-value kurang dari taraf nyata 5\% sehingga cukup bukti terdapat ketidaksamaan ragam spasial pada galat/sisaan. Hal ini menyebabkan adanya perbedaan karakteristik di setiap lokasi pengamatan.

\section{Analisis Regresi Terboboti Geografis}

Dengan fungsi pembobot adaptive Gaussian kernel, dengan menggunakan software Rstudio menghasilkan bandwidth optimum sebesar 0,2121065 dan CV sebesar 0,03472973. Pengujian kesesuaian model RTG dengan model regresi global dengan Uji F Brundson, Fotheringham, dan Charlton mengasilkan nilai $\mathrm{F}$ sebesar 2,3107 dan $p$-value sebesar 0,0456 sehingga dapat disimpulkan bahwa model RTG lebih sesuai daripada model regresi global karena dilihat dari nilai $p$-value kurang dari taraf nyata $5 \%$.

Tabel 2. Signifikansi Variabel Tiap Kabupaten/Kota

\begin{tabular}{llc}
\hline No & Kabupaten/Kota & Variabel \\
\hline \hline 1 & $\begin{array}{l}\text { Tapanuli Utara, Labuhan Batu, Humbang Hasundutan, Padang } \\
\text { Lawas, Labuhan Batu Selatan, Labuhan Batu Utara }\end{array}$ & $X_{2}$ \\
\hline 2 & Nias, Nias Utara, Nias Barat, Kota Gunungsitoli & $X_{1}, X_{2}$ \\
\hline & $\begin{array}{l}\text { Simalungun, Karo, Deli Serdang, Langkat, Nias Selatan, Serdang } \\
3\end{array}$ & $\begin{array}{l}\text { Bedagai, Batu Bara, Kota Pematang Siantar, Kota Tebing Tinggi, } \\
\text { Kota Medan, Kota Binjai }\end{array}$ \\
\hline 4 & Padang Lawas Utara, Kota Sibolga, Kota Padangsidimpuan & $X_{2}, X_{3}$ \\
\hline
\end{tabular}




\begin{tabular}{llc}
\hline 5 & Toba Samosir, Samosir & $X_{2}, X_{5}$ \\
\hline 6 & Mandailing Natal & $X_{2}, X_{6}$ \\
\hline 7 & Asahan, Dairi, Pakpak Bharat, Kota Tanjung Balai & $X_{1}, X_{2}, X_{5}$ \\
\hline 8 & Tapanuli Selatan, Tapanuli Tengah & $X_{2}, X_{3}, X_{6}$ \\
\hline
\end{tabular}

Selanjutnya dilakukan uji parsial parameter model RTG untuk mengetahui variabel apa saja yang berpengaruh secara signifikan terhadap IPKM sehingga dapat menaikkan nilai IPKM. Maka dari itu, diperoleh kelompok variabel yang berpengaruh secara signifikan dalam pemodelan RTG ditampilkan pada Tabel 2. Berdasarkan variabel signifikan pada taraf nyata 5\%, dapat dibentuk model RTG. Model yang terbentuk pada Kabupaten Nias adalah:

$$
\hat{y}_{1}=0,35895+0,0017 X_{1}+0,00157 X_{2}
$$

Selanjutnya dilakukan pengujian pengaruh lokasi secara parsial untuk mengetahui apakah terdapat perbedaan pengaruh yang signifikan dari setiap variabel bebas antara satu lokasi dengan lokasi yang lainnya. Dengan menggunakan software Rstudio, pada taraf nyata 5\% bahwa variabel persentase rumah tangga yang memiliki akses sanitasi layak dan tingkat kepadatan penduduk terdapat perbedaan pengaruh yang signifikan dari variabel bebas $X_{k}$ antara satu lokasi dengan lokasi yang lainnya. Yang artinya, dikarenakan tidak semua variabel bebas berpengaruh secara lokal maka untuk pengujian parsial parameter model sebaiknya dilakukan dengan menggunakan model Regresi Terboboti Geografis Semiparametrik (RTG-S).

\section{Analisis Regresi Terboboti Geografis Semiparametrik}

Berdasarkan analisis Regresi Terboboti Geografis (RTG) dengan pembobot adaptive gaussian kernel terdapat 2 variabel bebas yang berpengaruh secara lokal diantaranya $X_{1}$ dan $X_{3}$, Sedangkan 4 variabel bebas yang berpengaruh secara global yaitu $X_{2}, X_{4}, X_{5}$, dan $X_{6}$.

Tabel 3. Nilai Statistik Uji F Model RTG-S

\begin{tabular}{ccccc}
\hline & Fhitung & df1 & df2 & $p$-value \\
\hline F1 & 3.667501 & 26.36812 & 26.33778 & $6.912612 \mathrm{e}-04$ \\
\hline F2 & 3.862397 & 18.08241 & 26.33778 & $8.583846 \mathrm{e}-04$ \\
\hline F3 & 13.725307 & 27.09946 & 26.33778 & $1.127985 \mathrm{e}-09$ \\
\hline
\end{tabular}

Dari Tabel 3. dimana F1 untuk menguji tingkat kesesuaian model RTG-S dengan model regresi global dan menampilkan bahwa nilai $\mathrm{F}_{\text {hitung }}$ model RTG-S sebesar 3.667501 dan nilai $p$ value sebesar 6.912612e-04. Sehingga pada taraf nyata 5\% menyimpulkan bahwa model RTG$\mathrm{S}$ lebih sesuai daripada model regresi global karena $p$-value $<\alpha(0,05)$. Kemudian F2 untuk uji serentak parameter global RTG-S dan F3 untuk uji serentak parameter lokal RTG-S, hasil menunjukkan bahwa F2 dan F3 terdapat variabel bebas yang bersifat global maupun lokal secara serentak berpengaruh secara signifikan terhadap pemodelan IPKM di Sumatera Utara.

Uji parsial untuk variabel bebas yang bersifat global menghasilkan bahwa pada taraf nyata $5 \%$, persentase rumah tangga yang memiliki akses sumber air bersih dan persentase prevalensi obesitas sentral berpengaruh secara signifikan terhadap IPKM di kabupaten/kota Sumatera Utara. Uji parsial untuk variabel bebas yang bersifat lokal dilihat pada Tabel 4. dimana ada 3 kelompok yang terbentuk pada taraf nyata $5 \%$.

Tabel 4. Signifikansi Variabel Lokal Tiap Kabupaten/Kota

\begin{tabular}{llc}
\hline No & Kabupaten/Kota & Variabel \\
\hline \hline 1 & Karo, Labuhan Batu Selatan, Kota Tebing Tinggi & $X_{1}$ \\
\hline 2 & Nias, Asahan, Simalungun, Nias Utara, Nias Barat & $X_{3}$ \\
\hline & Mandailing Natal, Tapanuli Selatan, Tapanuli Tengah, Tapanuli Utara, & \\
& $\begin{array}{l}\text { Toba Samosir, Labuhan Batu, Dairi, Deli Serdang, Langkat, Nias } \\
3\end{array}$ & $\begin{array}{l}\text { Selatan, Humbang Hasundutan, Pakpak Bharat, Samosir, Serdang } \\
\text { Bedagai, Batu Bara, Padang Lawas Utara, Padang Lawas, Labuhan }\end{array}$ \\
& $\begin{array}{l}\text { Batu Utara, Kota Sibolga, Kota Tanjung Balai, Kota Pematang Siantar, } \\
\text { Kota Medan, Kota Binjai, Kota Padangsidimpuan, Kota Gunungsitoli }\end{array}$ \\
\hline
\end{tabular}

Maka dari itu, model yang dihasilkan dengan pembobot adaptive Gaussian kernel di 
Kabupaten Nias adalah:

$$
\hat{y}_{1}=0.3742694+0.0012439 X_{12}-0.0020642 X_{16}+7.1998 e^{-05} X_{13}
$$

Dengan interpretasi bahwa rata-rata IPKM di Kabupaten Nias sebesar 0.3742694 jika variabel $X_{2}, X_{6}$, dan $X_{1}$ tetap. Dan setiap kenaikan persentase rumah tangga yang memiliki akses sumber air bersih sebesar 1 persen maka nilai IPKM di Kabupaten Nias akan bertambah sebesar 0.0025482 persen dengan menganggap variabel $X_{6}$ dan $X_{3}$ tetap. Setiap kenaikan persentase prevalensi obesitas sentral sebesar 1 persen maka nilai IPKM di Kabupaten Nias akan berkurang sebesar 0.0020642 persen dengan menganggap variabel $X_{2}$ dan $X_{3}$ tetap. Setiap kenaikan tingkat kepadatan penduduk sebesar 1 persen maka nilai IPKM di Kabupaten Nias akan bertambah sebesar 7.1998e-05 persen dengan menganggap variabel $X_{2}$ dan $X_{6}$ tetap.

Berikut merupakan peta tematik untuk model RTG-S pada indeks kesehatan di Sumatera Utara tahun 2018 berdasarkan variabel signifikan adalah sebagai berikut.

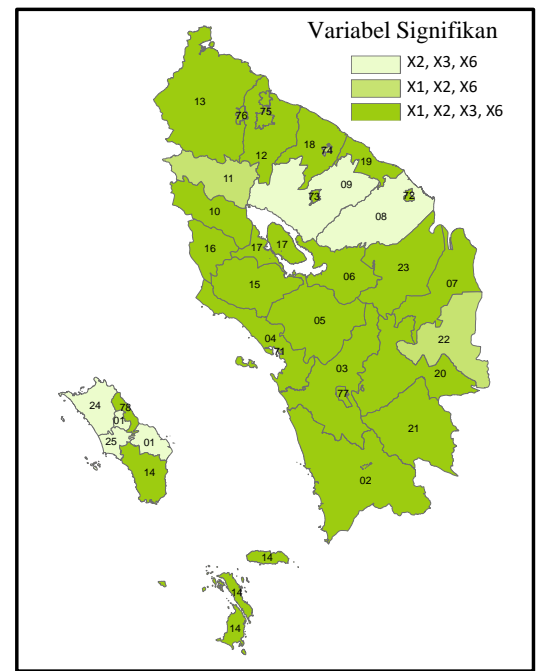

Gambar 2. Peta Tematik Model RTG-S

\section{Model Terbaik}

Tabel 5. menunjukkan bahwa Regresi Terboboti Geografis Semiparametrik (RTG-S) adalah model terbaik untuk IPKM di kabupaten/kota Sumatera Utara dilihat dari perolehan nilai $A I C_{c}$ terendah dan nilai $R^{2}$ terbesar.

Tabel 5. Perbandingan Model RTG dan RTG-S

\begin{tabular}{lll}
\hline Spesifikasi Model & $A I C_{c}$ & $R^{2}$ \\
\hline RTG & -114.2026 & 0.9316299 \\
\hline RTG-S & -790.9986 & 0.9591745 \\
\hline
\end{tabular}

\section{Kesimpulan}

Model regresi terboboti geografis semiparametrik untuk IPKM di Sumatera Utara tahun 2018 menunjukan model yang paling baik untuk digunakan karena menghasilkan nilai $R^{2}$ terbesar dan nilai $A I C_{c}$ terkecil. Model RTG-S yang terbentuk sebanyak 33 model. Terdapat 3 kabupaten/kota yang mempunyai variabel signifikan persentase rumah tangga yang memiliki akses sanitasi layak $\left(X_{1}\right)$, persentase rumah tangga yang memiliki akses sumber air bersih $\left(X_{2}\right)$, dan persentase prevalensi obesitas sentral $\left(X_{6}\right)$. Terdapat 5 kabupaten/kota yang mempunyai variabel signifikan persentase rumah tangga yang memiliki akses sumber air bersih $\left(X_{2}\right)$, tingkat kepadatan penduduk $\left(X_{3}\right)$, dan persentase prevalensi obesitas sentral $\left(X_{6}\right)$. Serta terdapat 25 kabupaten/kota yang mempunyai variabel signifikan persentase rumah tangga yang memiliki akses sanitasi layak $\left(X_{1}\right)$, persentase rumah tangga yang memiliki akses sumber air bersih $\left(X_{2}\right)$, tingkat kepadatan penduduk $\left(X_{3}\right)$, dan persentase prevalensi obesitas sentral $\left(X_{6}\right)$. Dimana 
variabel persentase rumah tangga yang memiliki akses sanitasi layak $\left(X_{I}\right)$ dan variabel tingkat kepadatan penduduk $\left(X_{3}\right)$ mempengaruhi IPKM secara lokal terhadap setiap wilayah di Sumatera Utara dan variabel persentase rumah tangga yang memiliki akses sumber air bersih $\left(X_{2}\right)$ dan variabel persentase prevalensi obesitas sentral $\left(X_{6}\right)$ mempengaruhi IPKM secara global untuk keseluruhan wilayah di Sumatera Utara.

\section{Acknowledge}

Terima kasih kepada seluruh pihak yang membantu memberi saran maupun masukan sampai terlaksananya penelitian ini.

\section{Daftar Pustaka}

[1] Djuraidah, A. (2020). Penerapan dan Pengembangan Regresi Spasial dengan Studi Kasus pada Kesehatan, Sosial, dan Ekonomi. PT Penerbit IPB Press.

[2] Fotheringham, A. S., Brunsdon, C., \& Charlton, M. (2002). Geographically Weighted Regression the analysis of spatially varying relationships. John Wiley \& Sons Ltd.

[3] Hajarisman, N., \& Karyana, Y. (2016). Geographic Modeling on the Infant Mortality Rate in West Java. Mimbar: Jurnal Sosial Dan Pembangunan, 32(1), 194-205. 